\section{An in vitro investigation of the erosive potential of smoothies}

\author{
S. M. Blacker ${ }^{1}$ and R. G. Chadwick ${ }^{* 2}$
}

VERIFIABLE CPD PAPER
IN BRIEF
- Reviews the current literature on
fruit smoothies.
- Evaluates the potential for fruit
smoothies to bring about dental erosion.
Recommends that fruit smoothie
consumption should be confined
to mealtimes in order to minimise
erosive risk.

\begin{abstract}
Introduction Recent health promotion campaigns have encouraged the public to consume at least five portions of fruit and vegetables per day. Many see consuming fruit smoothies as a way of achieving this. Objective To ascertain the potential or otherwise for fruit smoothies to bring about dental erosion. Design Laboratory study. Method This was an in vitro investigation in which five varieties of shop bought fruit smoothies, including a 'thickie' were investigated, with respect to their initial $\mathrm{pH}$, titratable acidity and effect upon exposure to the surface microhardness and profile of extracted human teeth. In addition their performance was compared to negative (Volvic ${ }^{\mathrm{TM}}$ water) and positive (orange juice) control drinks as well as a homemade smoothie, based upon the recipe of one of the commercially bought drinks, from which ingredient omissions were made.

Results The majority of the drinks investigated had a baseline $\mathrm{pH}$ below the critical $\mathrm{pH}$ of enamel (5.5) and required comparable volumes of $0.1 \mathrm{M} \mathrm{NaOH}$ to raise their $\mathrm{pH}$ to neutrality as the positive control. Only two drinks (Volvic ${ }^{\mathrm{TM}}$ still mineral water, the negative control, and the yoghurt, vanilla bean and honey 'thickie') displayed a higher $\mathrm{pH}$, though to neutralise the thickie, a lesser quantity of alkali addition was required. The immersion of the tooth samples in the drinks brought about reductions in their surface hardness (expressed as a percentage change of median hardness) but these were only significant $(p<0.001)$ for the cranberry, blueberry and cherry fruit smoothie and homemade strawberry and banana fruit smoothie. There was no reduction in surface hardness in the case of the teeth immersed in the thickie. Omission of certain ingredients from the homemade smoothie affected the magnitude of surface hardness reductions seen. With regard to the loss of surface contour of the tooth samples following immersion in the drinks, as assessed by depth loss, there were significant differences between the drinks ( $p=0.0064)$ with the thickie and negative control not causing depth loss and the kiwi, apple and lime smoothie producing most depth loss (28.26 (5.45) $\mathrm{um}$ ). Conclusions Within the limitations of this study some fruit smoothies have the potential to bring about dental erosion if consumed irresponsibly. This can be influenced by ingredient variations. In order to minimise the risk of developing dental erosion, without removing the claimed nutritional benefits of their consumption, their consumption should be confined to mealtimes.
\end{abstract}

\section{INTRODUCTION}

Dental erosion has been defined as the loss of tooth tissue by a chemical process not involving bacteria. ${ }^{1}$ In this condition, contact of the tooth structure with acids results in its dissolution. The complications of dental erosion range from minimal tooth surface loss (TSL), leading to sensitivity and pain, to excessive loss of

${ }^{1}$ Clinical Lecturer in Restorative Dentistry, ${ }^{2}$ Clinica Senior Lecturer in Restorative Dentistry and Honorary Consultant in Restorative Dentistry, The Dental School and Hospital, Park Place, Dundee, DD1 4HN

${ }^{*}$ Correspondence to: Dr R. G. Chadwick

Email: r.g.chadwick@dundee.ac.uk;

Tel: +44 (0)1382635984

\section{Online article number E8}

Refereed Paper - accepted 1 October 2012

DOI: 10.1038/sj.bdj.2013.164

${ }^{\circ}$ British Dental Journal 2013; 214: E8 clinical crown height, loss of vitality and poor dental aesthetics. Management of the condition ranges from the application of simple preventive measures and monitoring of their impact to restoration with composite filling materials or extensive treatment with indirect restorations such as onlays and crowns. This therefore can be a very time consuming and expensive condition to treat. ${ }^{2,3}$

Acids of intrinsic and extrinsic origin are thought to be the main aetiological factors for dental erosion. ${ }^{4}$ For many years exposure of the teeth to extrinsic acids in the diet have been seen to be a major contributory factor to the development of dental erosion. Many studies have identified both fruit-based drinks and carbonated drinks to be potentially erosive..$^{3,5-8}$
The UK government's 'five a day' campaign, has encouraged the public to consume at least five portions of fruit and vegetables per day ${ }^{9}$ to reduce the likelihood of developing serious medical conditions. Many patients see consuming fruit smoothies as a way of achieving this and this is reinforced further by the way such drinks are marketed internationally. One serving of fruit smoothie can be counted as up to two of an individuals' 'five-a-day'. ${ }^{10,11}$ The consumption of shopbought smoothies has risen dramatically, from 6.3 million litres in 2001 to 34 million litres in 2006, with consumption projected to treble over the next five years. ${ }^{12}$ However, the true level of smoothie consumption is not actually known as these figures exclude consumption of homemade 
smoothies and those made and purchased in cafés and juice bars.

Historically, fruit smoothies appear to have originated in Brazil as a product of juicing fruit. ${ }^{13}$ They first appeared in the UK in 1994 and have steadily increased their share of the soft drinks market.

Legally there is no definition of a fruit smoothie, but it is well accepted in the soft drinks industry that fruit smoothies are made only from pure fruit blended with 100\% pure fruit juice, (not from concentrate) with no other added ingredients, that is dairy, sugar, sweeteners or water. ${ }^{14}$ There are thus many varieties of fruit smoothies, made using different combinations of various fruits and these by their nature contain a variety of organic acids such as citric, malic, phosphoric, oxalic and tartaric. Exposure to such acids has the potential to cause dental erosion. ${ }^{15}$ There is nothing to suggest that the increased consumption of smoothies is limited to the UK, thus giving the potential risk of developing dental erosion from their consumption an international dimension.

A variation of the smoothie, though a distinct entity, is the 'thickie'. Thickies contain dairy in some form, usually in the form of yoghurt, with or without fruit. In the production of these drinks yoghurt is deliberately soured or milk curdled by adding bacteria (for example, Lactobacillus acidophilus), which breaks down the milk's lactose forming lactic acid. ${ }^{16}$ Although the resultant yoghurt has a low $\mathrm{pH}$, it has no erosive potential due to high levels of calcium and phosphate within it. ${ }^{17}$ In the 2008 UK soft drinks report ${ }^{18}$ juice and dairy containing drinks were highlighted as being 'set to hit the spotlight' in the future as they were considered 'health targeted products'. They identified that drinks containing dairy cultures conferred 'gut health benefits'18 as some of the yoghurts used are probiotic and help digestion.

At the time of commencing this work a review of the literature failed to find any research that had investigated the capacity of fruit smoothies to cause dental erosion. This in vitro work therefore sought to investigate the $\mathrm{pH}$ and titratable acidity of a range of fruit smoothies and observe the effects of exposure to them upon samples of human tooth tissue. In addition, the effects of the removal of fruit smoothie

\section{Table 1 The drinks investigated in the study}

\begin{tabular}{|c|c|c|}
\hline Drink & Manufacturer & $\begin{array}{l}\text { Contents (compiled from carton } \\
\text { contents label) }\end{array}$ \\
\hline Smooth orange juice (positive control) & Tropicana $^{\mathrm{TM}}$ & Juice of fresh oranges \\
\hline $\begin{array}{l}\text { Still mineral water } \\
\text { (negative control) }\end{array}$ & Volvic $^{\text {TM }}$ & Still mineral water \\
\hline Strawberry and bananas fruit smoothie & Innocent ${ }^{T M}$ & $\begin{array}{l}22 \text { crushed strawberries } \\
2 \text { pressed apples } \\
21 / 2 \text { mashed bananas } \\
11 / 2 \text { squeezed oranges } \\
21 \text { pressed red and white grapes } \\
\text { A squeeze of fresh lime juice }\end{array}$ \\
\hline Kiwis, apples and limes fruit smoothie & Innocent ${ }^{\mathrm{TM}}$ & $\begin{array}{l}31 / 2 \text { pressed apples } \\
1 / 3 \text { pressed pineapple } \\
2 \text { crushed kiwis } \\
21 \text { pressed red and white grapes } \\
1 / 2 \text { fresh lime } \\
\text { A dash of spinach and nettle extract }\end{array}$ \\
\hline $\begin{array}{l}\text { Pomegranates, blueberries } \\
\text { and açai fruit smoothie }\end{array}$ & Innocent ${ }^{\mathrm{TM}}$ & $\begin{array}{l}86 \text { pressed red and white grapes } \\
21 / 2 \text { mashed bananas } \\
11 / 2 \text { crushed pomegranate } \\
11 / 2 \text { squeezed oranges } \\
153 \text { crushed blueberries } \\
102 \text { peeled açai berries }\end{array}$ \\
\hline $\begin{array}{l}\text { Cranberries, blueberries } \\
\text { and cherries fruit smoothie }\end{array}$ & Innocent ${ }^{\mathrm{TM}}$ & $\begin{array}{l}4 \text { pressed apples } \\
54 \text { pressed red and white grapes } \\
29 \text { crushed cherries } \\
160 \text { crushed cranberries } \\
90 \text { crushed blueberries } \\
\text { A squeeze of fresh lime juice }\end{array}$ \\
\hline $\begin{array}{l}\text { Yoghurt, vanilla bean } \\
\text { and honey thickie }\end{array}$ & Innocent ${ }^{\mathrm{TM}}$ & $\begin{array}{l}\text { Fresh low-fat probiotic yoghurt } 73 \% \\
1 / 2 \text { pressed apple } \\
\text { Honey } 9 \% \\
\text { Vanilla } 0.1 \%\end{array}$ \\
\hline $\begin{array}{l}\text { 'Homemade' strawberry } \\
\text { and banana fruit smoothie* }\end{array}$ & Homemade & $\begin{array}{l}450 \mathrm{~g} \text { of strawberries } \\
200 \mathrm{~g} \text { of banana (mashed) } \\
315 \mathrm{~g} \text { of pressed apples (juice and pulp) } \\
215 \mathrm{~g} \text { of squeezed oranges (juice and pulp) } \\
125 \mathrm{~g} \text { of pressed green and black grapes } \\
\text { (juice and pulp) } \\
15 \mathrm{ml} \text { of freshly squeezed lime juice }\end{array}$ \\
\hline
\end{tabular}

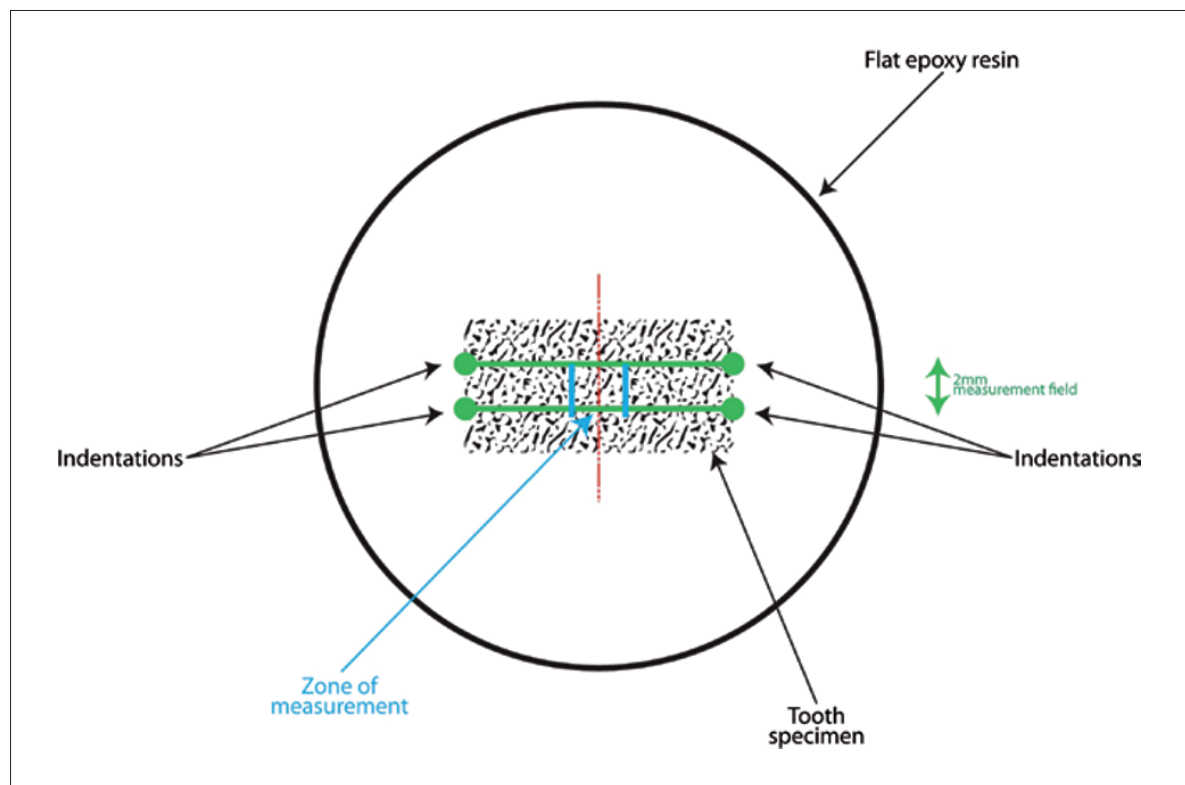

Fig. 1 The reference indentations in the epoxy resin to identify the zone of measurement. Green lines used to define upper and lower borders of zone of measurement. Blue lines demarcate its lateral borders. Red line indicates line of profilometers traverse 
constituents upon erosive potential were also investigated.

\section{MATERIALS AND METHODS}

This was an in vitro investigation in which five varieties of shop-bought fruit smoothies, including a 'thickie' were investigated, with respect to their initial $\mathrm{pH}$, titratable acidity and effect upon exposure to the surface microhardness and profile of extracted human teeth.

Before commencing the work ethical approval was sought and granted from the Tayside Committee on Medical Research Ethics Committee B (REC Reference Number 10/S1402/23).

Table 1 gives details of the drinks studied that also included positive (Tropicana ${ }^{\mathrm{TM}}$ smooth orange juice [0J]) and negative (Volvic $^{\mathrm{TM}}$ still mineral water [W]) control drinks, as well as a homemade fruit smoothie made using the Innocent ${ }^{\mathrm{TM}}$ strawberries and bananas fruit recipe as a guide, sourced from the carton label of the commercially available drink with the quantities of fruit used converted to grammes to ensure reproducibility. Five versions of this homemade strawberry and banana smoothie (HSB) were made for testing that omitted certain key ingredients:

- Strawberry omitted (HSBWS)

- Orange and lime omitted (HSBWOL)

- Banana omitted (HSBWB)

- Apple omitted (HSBWA)

- Grape omitted (HSBWG).

For each homemade smoothie all ingredients were placed within the jug of a commercially available smoothie maker (Kenwood Smoothie Maker SB 266, Kenwood Limited, Havant, Hampshire, P09 $2 \mathrm{NH}, \mathrm{UK})$ and blended for 120 seconds.

\section{Titratable acidity and initial pH measurement}

For each fruit smoothie and the positive control drink, five $100 \mathrm{ml}$ samples were titrated to a $\mathrm{pH}$ of 7.0 using $0.1 \mathrm{M}$ sodium hydroxide $(\mathrm{NaOH})$ while being stirred constantly with a magnetic stirrer set at a uniform rate. The initial $\mathrm{pH}$ and the change in $\mathrm{pH}$ by adding increments of $0.1 \mathrm{M} \mathrm{NaOH}$ were recorded using a calibrated temperature compensated $\mathrm{pH}$ electrode (Jenway 3,510, Barloworld Scientific Ltd, Essex, UK). The mean initial pH reading and volume of $0.1 \mathrm{M} \mathrm{NaOH}$ required to raise this to $\mathrm{pH} 7.0$ was recorded. The mean and standard deviation of these values were calculated for all the drinks. The mean titratable acidity values were also expressed as the standardised titratable acidity (STA). This is the mean volume of $0.1 \mathrm{M} \mathrm{NaOH}$ required to neutralise one litre of drink.

\section{Effect of exposure to the drinks upon surface microhardness and contour of tooth samples}

The effect of a 60 minute exposure to each drink was investigated using specially prepared samples of extracted, human buccal/ palatal enamel.

\section{Collection and preparation of tooth samples}

Extracted human molar teeth with buccal/palatal enamel were used in this study. Their fluoride history was unknown. In total 40 teeth were used in this study. In preparation their roots were removed and the resultant crown sectioned longitudinally to leave buccal and palatal halves. Each half was mounted with their buc$\mathrm{cal} /$ palatal face outermost in epoxy resin (Bonda Clear Casting Resin, Bondaglass Vost Ltd, Kent, UK) mixed according to the manufacturer's instructions. Once the resin was set this surface was finished flush with the surrounding mounting epoxy resin using a PM5 precision lapping and polishing machine (Longitech, Glasgow, Scotland) and a slurry of calcined aluminium oxide powder with a particle size of $9 \mu \mathrm{m}$ (Longitech, Glasgow, Scotland), for subsequent exposure to the test drinks (five teeth per drink).

Before the commencement of any experimental work, the surface microhardness and baseline surface profiles of all specimens were determined, following marking the specimens so that a $2 \mathrm{~mm}$ field of measurement was reproducibly identifiable. To achieve this, four indentations were made in the mounting epoxy resin as shown in Figure 1. When joined by two parallel lines $2 \mathrm{~mm}$ apart a zone of measurement was defined. Both surface hardness and profile measurements were made at the centre of this and across it as shown in this figure.

Following baseline measurement adhesive masking tape (UniBond $^{\mathrm{TM}}$ original DUCT tape black, Henkel Limited, Winsford,
Cheshire, CW7 3QY, UK) was applied to the tooth specimens to mask out their surfaces other than a $2 \mathrm{~mm}$ strip as detailed by the reference indentations. Following immersion in the drinks (see below for details), the tape was removed and measurement of the surface microhardness and profile was again undertaken. Before and following immersion all specimens were stored at $37^{\circ} \mathrm{C}$ in distilled water to prevent desiccation of the tooth specimens.

\section{Surface microhardness measurement}

Surface mircrohardness measurement was undertaken using a Vickers hardness microscope (Ernest Leitz Gmbh., D6330, Wetzlar, Germany) with a load of sufficient magnitude, typically 200-300 g), to produce a measureable indent. This was applied for 20 seconds for each indent in the central region of the specimen. Each specimen was subjected to five indentations before and following immersion.

For each drink the results were expressed as the median Vickers hardness value and range of these observations. In addition the overall reduction in surface hardness for each drink, normalised to a percentage reduction to permit comparison, was calculated by:

Percentage reduction in surface hardness = (median initial hardness - median final hardness)/(median initial hardness) $\times 100$.

\section{Surface profile determination}

For each specimen the surface profile was determined before and following immersion for 60 minutes in the test beverage. Measurement was carried out using a profilometer (Surface Type SF 220, Planner Products Ltd Sunbury on Thames, UK) with a stylus tip of diameter $20 \mu \mathrm{m}$. The speed of traverse was $10 \mathrm{~mm} / \mathrm{min}$. The instrument software was used to calculate the mean depth loss relative to the masked surrounding tooth specimen. For each treatment regime, the results were expressed as the mean depth loss before and after immersion. Before immersion all specimens were checked using the profilometer to ensure that they were flat. Any which were not were rejected and replaced.

\section{Specimen immersion regime}

Following masking of the specimen 
surface to demarcate the zone of measurement, the prepared tooth in its mould was placed in a $1000 \mathrm{ml}$ sealable plastic container (Addis Clip and Close, Addis GP Ltd, Swansea, UK) with the tooth facing upwards. This was carried out for each group of fruit smoothies. The plastic container was placed on the flat bed of a Stuart mini orbital shaker (Barloworld Scientific Ltd., Stone, Staffordshire, UK) and $500 \mathrm{ml}$ of the drink, taken direct from the fridge at $4{ }^{\circ} \mathrm{C}$, was added. The container was sealed and the orbital shaker set in motion at 70 revolutions per minute for 60 minutes. After 60 minutes, the specimens were removed and washed in distilled water to remove any 'erosive debris'. After rinsing, the masking tape was removed and the specimens were stored in distilled water at $37{ }^{\circ} \mathrm{C}$ until measurement of surface hardness and profiles was undertaken.

All statistical analysis of results was carried out using the statistical package Prism (GraphPad Prism ${ }^{\circledR}$, Version 4, GraphPad Software Inc., San Diego, USA).

\section{RESULTS}

\section{$\mathrm{pH}$, titratable acidity and STA}

Table 2 summarises, for all the drinks investigated in this study, the mean baseline $\mathrm{pH}$ reading, mean titratable acidity and the standardised titratable acidity (STA) including the standard deviation of these observations.

Analyses of variance of the baseline $\mathrm{pH}$ readings and of the titratable acidity of the drinks revealed, for both parameters, significant differences $(\mathrm{p}<0.001)$ between the drinks. These were localised by Tukey comparison of means tests, as summarised in Tables 3 and 4 respectively.

From Table 2 it is clear that the majority of the drinks investigated had a baseline $\mathrm{pH}$ below the critical $\mathrm{pH}$ of 5.5. Only two drinks had a mean initial $\mathrm{pH}$ above this level - these were the negative control - Volvic ${ }^{\mathrm{TM}}$ still mineral water (W) and the yoghurt, vanilla bean and honey 'thickie' (YVT).

With regard to titratable acidity (Table 2) the homemade strawberry and banana fruit smoothie (HSB) required a greater addition of $0.1 \mathrm{M} \mathrm{NaOH}$ than the shop-bought smoothie (SB) (78.94 $\mathrm{ml}$ and $72.68 \mathrm{ml}$ respectively). YVT was the drink

Table 2 The mean baseline $\mathrm{pH}$ readings, titratable acidity and standardised titratable acidity (STA) of the fruit smoothies and the positive and negative control drinks

\begin{tabular}{|l|l|l|l|l|l|l|l} 
Drink & $\mathrm{pH}$ & $\begin{array}{l}\text { Mean titrat- } \\
\text { able acidity } \\
\text { (mls of } \\
0.1 \mathrm{M} \mathrm{NaOH})\end{array}$ & STA & Drink & $\mathrm{pH}$ & $\begin{array}{l}\text { Mean titrat- } \\
\text { able acidity } \\
\text { (mls of } \\
0.1 \mathrm{M} \mathrm{NaOH})\end{array}$ & STA \\
\hline W & $8.08(0.05)$ & - & - & PBA & $\begin{array}{l}5.29 \\
(0.01)\end{array}$ & $76.86(1.00)$ & $7.69 \times 10^{-2}$ \\
\hline OJ & $5.39(0.01)$ & $81.30(0.48)$ & $8.13 \times 10^{-2}$ & CBC & $\begin{array}{l}5.07 \\
(0.07)\end{array}$ & $\begin{array}{l}81.26(0.90) \\
n=6\end{array}$ & $8.13 \times 10^{-2}$ \\
\hline SB & $\begin{array}{l}5.33(0.03) \\
n=6\end{array}$ & $\begin{array}{l}72.68(0.41) \\
n=6\end{array}$ & $7.27 \times 10^{-2}$ & WT & $\begin{array}{l}5.70 \\
(0.05)\end{array}$ & $66.34(1.28)$ & $6.63 \times 10^{-2}$ \\
\hline KAL & $5.04(0.01)$ & $\begin{array}{l}79.60(0.42) \\
n=6\end{array}$ & $7.96 \times 10^{-2}$ & HSB & $\begin{array}{l}5.31 \\
(0.02)\end{array}$ & $78.94(4.16)$ & $7.89 \times 10^{-2}$ \\
\hline
\end{tabular}

Key: W - Volvic' still mineral water; OJ - Tropicana"' smooth orange juice; SB - Innocent" Strawberries and bananas fruit smoothie;

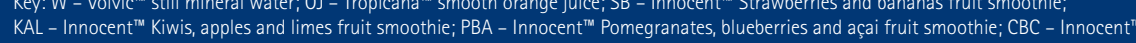
Cranberry, blueberry and cherry fruit smoothie; WT - Innocent" Yoghurt, vanilla bean and honey thickie; HSB - Homemade strawberry and Cranberry, blueberry and cherry fruit smoothie; WT - Innocent" Yoghurt, vanilla bean and honey thickie; HSB - Homemade strawberry and
banana fruit smoothie; the values in the main table represent the mean initial pH readings. Parenthesised values are the standard deviation. The mean is the result of five experimental runs except for the strawberry and banana fruit smoothie where six runs were undertaken; STA = stancardised titratable acidity $\left(\mathrm{mol} / \mathrm{L} \times 10^{-2}\right)$

Table 3 Summary of Tukey Comparison of means of the mean pH readings for all drinks investigated

\begin{tabular}{l|l|l|l|l|l|l|l|l}
\hline Versus & W & OJ & SB & KAL & PBA & CBC & WT & HSB \\
\hline W & - & $* * *$ & $* * *$ & $* * *$ & $* * *$ & $* * *$ & $* * *$ & $* * *$ \\
\hline OJ & $* * *$ & - & NS & $* * *$ & $* *$ & $* * *$ & $* * *$ & $*$ \\
\hline SB & $* * *$ & NS & - & $* * *$ & NS & $* * *$ & $* * *$ & NS \\
\hline KAL & $* * *$ & $* * *$ & $* * *$ & - & $* * *$ & NS & $* * *$ & $* * *$ \\
\hline PBA & $* * *$ & $* *$ & NS & $* * *$ & - & $* * *$ & $* * *$ & NS \\
\hline CBC & $* * *$ & $* * *$ & $* * *$ & NS & $* * *$ & - & $* * *$ & $* * *$ \\
\hline WT & $* * *$ & $* * *$ & $* * *$ & $* * *$ & $* * *$ & $* * *$ & - & $* * *$ \\
\hline HSB & $* * *$ & $*$ & NS & $* * *$ & NS & $* * *$ & $* * *$ & -
\end{tabular}

Key: W - Volvic's still mineral water; OJ - Tropicana"'s smooth orange juice; SB - Innocent" Strawberries and bananas fruit smoothie: KAL - Innocent"' Kiwis, apples and limes fruit smoothie; PBA - Innocent"' Pomegranates, blueberries and açai fruit smoothie; CBC - Innocent Cranberry, blueberry and cherry fruit smoothie; WT - Innocent"' Yoghurt, vanilla bean and honey thickie; HSB - Homemade strawberry and banana fruit smoothie; NS - No statistical difference; ${ }^{*} p<0.05_{;}^{* *} p<0.01 ;$

Table 4 Summary of Tukey comparison of means of the mean titratable acidity

\begin{tabular}{l|l|l|l|l|l|l|l} 
Versus & OJ & SB & KAL & PBA & CBC & WT & HSB \\
\hline OJ & - & $* * *$ & NS & $* *$ & NS & $* * *$ & NS \\
\hline SB & $* * *$ & - & $* * *$ & $*$ & $* * *$ & $* * *$ & $* * *$ \\
\hline KAL & NS & $* * *$ & - & NS & NS & $* * *$ & NS \\
\hline PBA & $* *$ & $* *$ & NS & - & $* *$ & $* * *$ & NS \\
\hline CBC & NS & $* * *$ & NS & $* *$ & - & $* * *$ & NS \\
\hline WT & $* * *$ & $* * *$ & $* * *$ & $* * *$ & $* * *$ & - & $* * *$ \\
\hline HSB & NS & $* * *$ & NS & NS & NS & $* * *$ & -
\end{tabular}

Key: W - Volvic" still mineral water; OJ - Tropicana" smooth orange juice; SB - Innocent" Strawberries and bananas fruit smoothie; Key: W - Volvic" still mineral water, OJ - Tropicana" "smooth orange juice; SB - Innocent" "Strawberries and bananas fruit smoothie;
KAL - Innocent" Kiwis, apples and limes fruit smoothie; PBA - Innocent" Pomegranates, blueberries and açai fruit smoothie; CBC - Innocent"

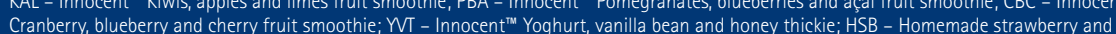
banana fruit smoothie; NS - No statistical difference; " ${ }^{*}<0.05 ;{ }^{* * p}<<0.01 ; *{ }^{* * *} p<0.001$

that required the least amount of $0.1 \mathrm{M}$ $\mathrm{NaOH}$ to be added to bring its $\mathrm{pH}$ to 7.00 at $66.34 \mathrm{ml}$.

Table 3 summarises the results of the
Tukey comparison of the mean $\mathrm{pH}$ readings for the drinks. The differences in mean $\mathrm{pH}$ readings were statistically significantly different with the exceptions of SB versus 


\begin{tabular}{|c|c|c|c|c|c|c|c|}
\hline Drink & $\begin{array}{l}\text { Initial } \\
\text { median } \\
\text { hardness }\end{array}$ & $\begin{array}{l}\text { Final } \\
\text { median } \\
\text { hardness }\end{array}$ & $\begin{array}{l}\text { Percentage } \\
\text { change in } \\
\text { hardness }\end{array}$ & Drink & $\begin{array}{l}\text { Initial } \\
\text { median } \\
\text { hardness }\end{array}$ & $\begin{array}{l}\text { Final } \\
\text { median } \\
\text { hardness }\end{array}$ & $\begin{array}{l}\text { Percentage } \\
\text { change in } \\
\text { hardness }\end{array}$ \\
\hline W & $\begin{array}{l}308.0 \\
(219.5,357.0)\end{array}$ & $\begin{array}{l}294.0 \\
(122.5,335.0)\end{array}$ & -0.55 & PBA & $\begin{array}{l}315.0 \\
(163.5,348.0)\end{array}$ & $\begin{array}{l}249.5 \\
(56.0,294.0)\end{array}$ & -20.79 \\
\hline OJ & $\begin{array}{l}212.5 \\
(68.0,308.0)\end{array}$ & $\begin{array}{l}58.5 \\
(42.0,223.0)\end{array}$ & -72.47 & $\mathrm{CBC}$ & $\begin{array}{l}311.5 \\
(225.5,375.0)\end{array}$ & $\begin{array}{l}223.0 \\
(50.0,275.0)\end{array}$ & -28.41 \\
\hline SB & $\begin{array}{l}335.0 \\
(287.5,375.0)\end{array}$ & $\begin{array}{l}210.0 \\
(168.0,244.0)\end{array}$ & -37.31 & YTT & $\begin{array}{l}290.5 \\
(129.0,335.0)\end{array}$ & $\begin{array}{l}269.0 \\
(223.0,315.0)\end{array}$ & +7.40 \\
\hline KAL & $\begin{array}{l}244.5 \\
(77.0,366.0)\end{array}$ & $\begin{array}{l}177.5 \\
(50.0,297.0)\end{array}$ & -27.40 & HSB & $\begin{array}{l}339.0 \\
(301.0,361.5)\end{array}$ & $\begin{array}{l}225.0 \\
(128.0,275.0)\end{array}$ & -33.63 \\
\hline HSBWS & $\begin{array}{l}278.0 \\
(73.5,323.0)\end{array}$ & $\begin{array}{l}169.0 \\
(54.0,223.0)\end{array}$ & -39.21 & HSBWB & $\begin{array}{l}287.0 \\
(72.5,315.0)\end{array}$ & $\begin{array}{l}180.5 \text { (36.5, } \\
223.0)\end{array}$ & -37.12 \\
\hline \multirow[t]{2}{*}{ HSBWOL } & $\begin{array}{l}272.0 \\
(142.5,327.0)\end{array}$ & $\begin{array}{l}223.0 \\
(73.0,272.0)\end{array}$ & -18.02 & HSBWA & $\begin{array}{l}361.5 \\
(291.0,429.0)\end{array}$ & $\begin{array}{l}275.0 \\
(58.0,327.0)\end{array}$ & -23.93 \\
\hline & & & & HSBWG & $\begin{array}{l}339.0 \\
(179.5,385.0)\end{array}$ & $\begin{array}{l}222.5 \\
(50.5,297.5)\end{array}$ & -34.37 \\
\hline $\begin{array}{l}\text { Key: W - Vo } \\
\text { WT - Innoce } \\
\text { banana fruit } \\
\text { HSBWS - Hc } \\
\text { lime; HSBW } \\
\text { HSBWG - H }\end{array}$ & & & & nd cherry fru & smoothie; OJ - Tropi & $\begin{array}{l}\text { ana" smooth orange } \\
\text { ie; HSB - Homemade }\end{array}$ & $\begin{array}{l}\text { juice; } \\
\text { strawberry and } \\
\text { iruit smothie; } \\
\text { vithout orangel } \\
\text { without apple; } \\
\text { parentheses }\end{array}$ \\
\hline
\end{tabular}

Table 6 The mean depth loss of tooth substance following immersion, with standardised agitation, for one hour in the drinks studied (shop bought and permutations of the homemade strawberry and banana fruit smoothie)

\begin{tabular}{l|l|l|l}
\hline Drink & Mean depth loss $(\mu \mathrm{m})$ & Drink & Mean depth loss $(\mu \mathrm{m})$ \\
\hline W & -0.13 & PBA & $\begin{array}{l}-3.36 \\
(3.36)\end{array}$ \\
\hline \multirow{2}{*}{ OJ } & $(1.99)$ & CBC & -10.79 \\
& -15.39 & & $(8.32)$ \\
\hline \multirow{2}{*}{ SB } & $(16.11)$ & HVT & +0.36 \\
& -1.90 & & $(2.26)$ \\
\hline \multirow{2}{*}{ KAL } & $(3.72)$ & HSB & -2.77 \\
& $n=4$ & & $(2.81)$ \\
& -28.26 & HSBWB & -4.99 \\
\hline \multirow{3}{*}{ HSBWS } & $(5.45)$ & & $(2.48)$ \\
& -3.90 & HSBWA & -2.65 \\
\hline \multirow{2}{*}{ HSBWG } & $(4.04)$ & & $(0.52)$ \\
& $n=4$ & & $n=3$ \\
\hline \multirow{2}{*}{ HSBWOL } & -1.82 & & \\
& $n=4$ & & \\
\hline
\end{tabular}

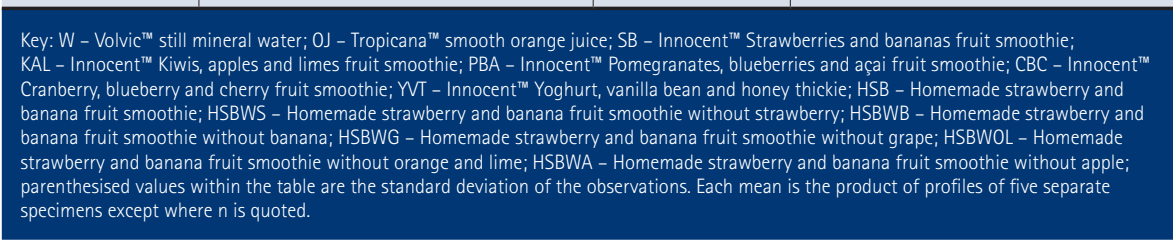

OJ, PBA versus $\mathrm{HSB}, \mathrm{KAL}$ versus $\mathrm{CBC}$ and HSB versus $\mathrm{PBC}$.

Table 4 summarises the results of the Tukey comparison of the mean titratable acidity values. There were no statistically significant differences $(\mathrm{p}>0.05)$ in the mean titratable acidity readings between all drinks with the exceptions of: OJ versus KAL, CBC summarises the percentile and median hardness values and also the percentage change in median hardness that occurred following immersion of the teeth in the beverages.

A Kruskal-Wallis test was performed that revealed highly significant differences ( $p<0.001$ ) in the surface hardness values between the groups $(\mathrm{H}=185)$. Accordingly, a Dunn's multiple comparison test was performed to localise these. This demonstrated that for the fruit smoothie drinks, the only two drinks that showed a significant difference ( $p<0.001$ ) between the initial and final surface microhardness readings were CBC and HSB.

It is interesting to note that immersion in all drinks except YVT resulted in a reduction in surface hardness.

With regard to the tooth samples exposed to the various ingredient permutations of the HSB the hardness values were not normally distributed. Table 5 endeavours to highlight the constituents responsible for the observed changes in surface microhardness. It is interesting to note that HSBWOC displayed the smallest reduction in surface hardness of the homemade smoothie variants, whereas removal of all the other individual constituents generally resulted in similar reductions in surface microhardness of the tooth samples. A Kruskal-Wallis test of this data revealed highly significant differences ( $p<0.001)$ in the surface hardness values between the groups $(\mathrm{H}=175.7)$. Localisation by Dunn's multiple comparison test demonstrated that in all cases for the homemade fruit smoothie the median surface hardness following exposure was significantly reduced from the initial median hardness except where orange juice was omitted (HSBWOL). The post immersion median surface hardness values of HSBWP were statistically significantly ( $p<0.001$ ) lower than the initial median hardness values of all other drink variants.

\section{Surface contour}

In relation to the results obtained, a normality test was not possible to carry out for all groups as some had less than five samples in them. The data was therefore analysed assuming the data were not normally distributed using a Kruskal-Wallis and Dunn's multiple comparison test.

Table 6 summarises the mean depth loss of tooth substance following immersion, 
with standardised agitation, for one hour in all the shop-bought fruit smoothies and permutations of the homemade smoothie. The fruit smoothie that caused the largest amount of sample tissue loss was KAL at $28.26 \mu \mathrm{m}$. It can be seen that the negative control W did not cause any tissue loss. Interestingly, YVT appeared to induce tissue formation. Surprisingly, the shop-bought strawberry and banana fruit smoothie (SB) resulted in less sample tissue loss compared to the homemade version HSB, at $1.90 \mu \mathrm{m}$ and $2.77 \mu \mathrm{m}$ respectively. A KruskalWallis test revealed significant differences ( $p=0.0064$ ) between the observed mean depth losses. Localisation by a Dunn's multiple comparison test revealed these to be significant $(\mathrm{p}<0.05)$ only between KAL and both water and YVT.

In relation to the homemade smoothie with omissions, non-inclusion of the orange component resulted in the largest reduction in depth loss $(8.55 \mu \mathrm{m})$. The version that had least effect on the sample of tooth tissue was HSBWG $(1.82 \mu \mathrm{m})$. Such changes in depth loss were, however, of no statistical significance ( $p=0.6,694)$, determined using the Kruskall-Wallis test as normality of the data was not assumed due to the sample size in some cases being less than five.

\section{DISCUSSION}

In this work three commonly used laboratory tests (acid/base titration, Vicker's surface microhardness and profilometry) were used to investigate the potential of the drinks to bring about dental erosion in vitro. All the methods used in this study have the limitation that they cannot replicate exactly the conditions encountered in the oral environment but they do enable one variable at a time to be studied under carefully controlled conditions and their performance compared to control drinks. As no human subjects are directly involved in drink consumption there is minimal risk and so longer exposure times can be used than would be encountered in vivo. In this context it should noted that tooth substance loss in such tests is considered to be ten fold greater than would occur intra-orally. ${ }^{8}$

The commercial smoothies investigated in this study were selected as they represented world brand leaders whose constituents were readily declared. Their inclusion did not imply that they were considered by the researchers to be any better/worse than competitor beverages.

\section{Baseline $\mathrm{pH}$ and titratable acidity (STA)}

The methods used to measure baseline $\mathrm{pH}$ and the titratable acidity were similar to that used by others. ${ }^{14-21}$ In the present study, however, $100 \mathrm{ml}$ of drink was used due to the thickness of both the fruit smoothies and the yoghurt 'thickie' investigated. On a practical basis such a volume promoted the efficient mixing of drink and chemical reagents. In contrast, other beverage studies only used $20 \mathrm{ml}$ of drink, perhaps due to the lower viscosities of the drinks under investigation. ${ }^{21}$ In the present work a non-heating magnetic stirrer, set at the highest stirring rate was used to provide sufficient momentum to permit mixing due to the drinks' thick consistencies. As Shellis et al. found, stirring rate influences both the rate of erosion and rate of dissolution of tooth substance so this was kept constant in the work reported here. ${ }^{22}$

It is recommended that smoothies are stored in a fridge and so, when determining $\mathrm{pH}$ and titratable acidity, these tests were conducted as soon as practicable, upon removal of the drink from the fridge, which was at a temperature of $4{ }^{\circ} \mathrm{C}$. Although the quantity of $0.1 \mathrm{M}$ $\mathrm{NaOH}$ required to bring about neutrality of the drinks is reported in this study, the standardised titratable acidity (STA) is also given, as advocated by Syed and Chadwick to permit ready inter study comparisons. ${ }^{23}$

Although much literature exists upon the $\mathrm{pH}$ and titratable acidity of single fruit juices no published work to date has examined combinations of fruit juices, such as those found in fruit smoothies, with one exception. ${ }^{21}$ Most work hitherto has focused on orange, apple, grapefruit and lemon juice and more exotic fruit juices such as blackcurrant, guava, apricot and grape..$^{24-28}$ Although Blacker et al. ${ }^{20}$ investigated the $\mathrm{pH}$ and titratable acidity of smoothies it is difficult to compare the results with the present work as only one fruit smoothie is common to both studies; the shop-bought strawberry and banana fruit smoothie. In addition, testing was carried out in the previous study at room temperature. Therefore, comparison between the studies is not practicable. Increases in temperature have been demonstrated to increase acid dissociation with an erosive drink..$^{27,29}$
In this work there were significant differences between the drinks tested in the present study in terms of baseline $\mathrm{pH}$ reading and titratable acidity (Table 2). The variations observed are probably a reflection of the complex interplay of different acid constituents and certainly worthy of detailed future chemical analysis. It is interesting to note that all the smoothies examined had $\mathrm{pH}$ values less than 5.5 and titratable acidity values approaching that of the positive control drink. They thus had the capacity, on this basis, to bring about dental erosion. In terms of $\mathrm{pH}$ the exception to the statement was the Innocent ${ }^{\text {TM }}$ yoghurt, vanilla bean and honey 'thickie' (YVT), which had a mean baseline $\mathrm{pH}$ reading of 5.70. On first examination this appears to be at odds with the work of Bamise and Bamise who investigated the acidic content of commercially available yoghurt drinks in Nigeria. ${ }^{30}$ The yoghurt drinks which they investigated, however, were fruit-based and displayed baseline pHs that ranged from 3.51 to 4.12. Such differences could be accounted for by the fact that the Nigerian yoghurt drinks investigated contained fruit concentrate and stabilisers whereas the Innocent ${ }^{\text {TM }}$ yoghurt, vanilla bean and honey 'thickie' investigated in the present study did not contain any fruit. Touyz found that products from fruits were always acidic whether they were fresh, juiced or dried. ${ }^{31}$ The presence of fruit would therefore lower the $\mathrm{pH}$ and account for the apparent difference seen.

In terms of titratable acidity the yoghurt, vanilla bean and honey 'thickie' (YVT) required the least amount of $0.1 \mathrm{M} \mathrm{NaOH}$ to neutralise it compared with the other drinks (Table 2). This could be accounted for by the fact that this drink did not contain any source of fruit and contained dairy products unlike the other drinks investigated. Other in vitro studies have demonstrated that the addition of calcium to both orange juice ${ }^{32}$ and in the form of UHT milk to carbonated beverages ${ }^{23}$ reduces titratable acidity, thus reducing the potential to bring about dental erosion.

Despite being of similar recipe to the shop-bought variety the homemade version of the strawberry and banana fruit smoothie (HSB) required more $0.1 \mathrm{M} \mathrm{NaOH}$ to neutralise it. Various reasons could account for this finding that include the 
use of different fruit varieties, fruit at different stages of ripening and also possible heightened acid activity due to the relative freshness of the homemade smoothie. Grobler et al. ${ }^{25}$ found that the amount or proportion of acids found in fruit varied from fruit to fruit, between different varieties of the same fruit and fruit in different stages of ripeness. It should be pointed out that Innocent ${ }^{\mathrm{TM}}$ fruit smoothies do not contain any preservatives or stabilisers but are gently pasteurised, during which degradation of acids may occur. ${ }^{33}$

\section{Surface hardness and profilometry}

This work sought to assess the effects of immersion of prepared human tooth samples upon these parameters. In discussing this it is important to note that the fluoride history of the teeth used, by virtue of the anonymous nature of donation, was unknown. Fluoride incorporation into the apatite lattice has been shown to be protective against erosion. ${ }^{34}$

In relation to tooth sample preparation a precision lapping machine was used to flatten and polish the tooth samples tested in preparation for pre- and postexposure profiling. In this process it is inevitable that the enamel tested by both profilometry and hardness determination was subsurface enamel and may also have included zones of dentine. Subsequent exposure of these samples to the drink may therefore have resulted in an artificially elevated measurement of tooth surface loss, as dentine is softer than enamel and more susceptible to softening upon acid exposure. Although in a recent literature review Barbour et al. stated that 'dentine dissolution is less dependent on $\mathrm{pH}$ and buffer capacity than enamel dissolution and does not necessarily erode faster. ${ }^{35}$ In contrast Barbour and Rees commented that the underlying layer of inner enamel is known to be more soluble and therefore erosion occurs more quickly. ${ }^{36}$

Profilometry has been described as the best method for measuring tooth surface loss especially in the advanced stages ${ }^{37}$ and has been used with success in many other erosion studies. ${ }^{38}$ Similarly, surface microhardness determination, of the type used in this study, has been used to assess the level of enamel and dentine dissolution following drink immersion. ${ }^{38}$ It is said to be capable of discriminating the erosive potentials of acids even after a short application to tooth substance. ${ }^{39}$

Some have recently suggested that Vickers hardness testers may lack sensitivity for deeper depth penetration, hindered by contact of the indentor with the underlying/surrounding sound enamel. ${ }^{36}$ It therefore follows that the reductions in surface hardness seen in the present study could be an underestimate.

The surface microhardness data in the present study was found not to conform to a normal distribution. This phenomenon has been reported by other workers in studies upon extracted teeth when assessing topical fluoride applications in primary teeth, ${ }^{40}$ incisor caries micromechanics, ${ }^{41}$ effects of antihistamine medication upon primary enamel ${ }^{42}$ and the effects of carbamide peroxide on enamel and dentine. ${ }^{43}$ It was for this reason that the statistical analyses of the hardness data utilised nonparametric methods.

of all the drinks investigated, the Innocent ${ }^{\mathrm{TM}}$ yoghurt, vanilla bean and honey 'thickie' (YVT) showed the least reduction in tooth substance surface hardness (Table 5). This finding could be explained by the presence of high calcium and phosphate ions in the yoghurt that prevent the dissolution of dental enamel by the law of mass action, therefore making it more resistant to indentation. ${ }^{23}$ Similarly Gedalia et al. found acid softened enamel samples were rehardened after exposure to milk. ${ }^{44}$

Upon removing the acidic constituent of orange/lime juice from the homemade strawberry and banana fruit smoothie there was less reduction in surface microhardness (Table 5) than when these constituents remained. This, however, is at odds with the greater depth loss seen when orange/lime juice was removed from the drink (Table 6).

With reference to the changes in surface contour seen of all the fruit smoothies investigated, the kiwi, apple and lime smoothie (KAL) produced the most tooth substance loss at $28.26 \mu \mathrm{m}$ after immersion for 60 minutes (Table 6). This was nearly double the amount of tooth loss produced by the next erosive drink, which was fresh orange juice (OJ) (positive control) at $15.39 \mu \mathrm{m}$. It is generally considered that in laboratory tests orange juice removes $4 \mu \mathrm{m}$ per hour. ${ }^{24}$ The elimination of orange/lime juice from the homemade smoothie markedly reduced the depth loss seen (Table 6). Although apples contain citric acid (3\%), their major acid constituent is malic acid (95\%) ${ }^{25}$ and this, coupled with presence of citric acid from the lime and kiwi fruit, may account for the considerable reduction in surface hardness seen for the kiwi, apple and lime fruit smoothie (KAL). It should also be borne in mind that assessments of erosive potential should use a variety of tests to gain an overall assessment, for no single test has proven to be a reliable predictor of tooth tissue loss. ${ }^{38}$

Plain yoghurt, as used in the dairy-based smoothie tested in this work, is a low $\mathrm{pH}$ food $^{34}$ recognised as being non-erosive due to its calcium and phosphate constituents and buffer capacity. It was therefore not surprising to see that the Innocent ${ }^{\mathrm{TM}}$ yoghurt, vanilla bean and honey 'thickie' (YVT) produced no tooth surface loss (Table 6) or deterioration in surface microhardness (Table 5). The increases in the amount of tooth structure and hardness seen could be the result of deposition of organic and mineral material upon the surface of the affected tooth samples. ${ }^{44}$

\section{Wider implications}

Although the yoghurt 'thickie' drink (YVT) was not dentally erosive in this study, it contains $29.89 \mathrm{~g}$ of fermentable carbohydrate per $250 \mathrm{ml}$ bottle according to the manufacturers' data. Such a level of carbohydrate is classed as high, (15 g per $100 \mathrm{~g}$ ) and therefore regular consumption of such beverages, due to the risk of developing dental caries, is not recommended by some. ${ }^{45}$ It may therefore not be wise to advocate this as an alternative type of 'safer' smoothie in a patient with dental erosion.

Various organisations and government bodies have advocated the consumption of fruit on a daily basis, citing fruit smoothies as a valid source. ${ }^{46,47}$ A recent survey showed $60 \%$ of parents gave their children fruit smoothies as they felt it was an easy way for them to consume their fruit portions. ${ }^{48}$ Recently the World Health Organization (WHO) developed nutritional education guidelines to encourage the development of nutrition education in health promoting schools in Europe. ${ }^{49}$ In the spirit of this the Scottish Government have issued guidelines on what can be consumed as a drink in school premises as part of their policy document Healthy eating in schools - a guide to implementing 
the nutritional requirements for food and drink in schools (Scotland) Regulations 2008. ${ }^{50}$ Permitted drinks include plain water (still or carbonated), milk drinks and drinking yoghurts, fruit juices and blends of these. In these regulations lunchtime consumption of fruit juice is limited to a portion size of no more than $200 \mathrm{ml}$. It is, however, known that other drinks are consumed in school hours and these are either brought in lunchboxes from home (71\% of drinks consumed within school) or purchased at school (26\% of drinks consumed within school) ${ }^{11}$ and their quantity and consumption is therefore outside of controlled mealtimes. It is therefore likely that some children may snack on fruit smoothies as they are perceived to be nutritionally healthy. If this is frequently carried out the results of this in vitro study, with its limitations, suggests they may be heightening their risk of developing dental erosion. Such a practice should therefore be discouraged and any claimed nutritional benefits of smoothie consumption be reaped at mealtimes only.

The authors are grateful to the Oral and Dental Research Trust for funding this work through a Glaxo SmithKline project grant.

1. Pindborg J J. Pathology of the dental hard tissues. Copenhagen: Munksgaard, 1970

2. Gandara B K, Truelove E L. Diagnosis and management of dental erosion. J Contemp Dent Pract 1999. 1: 16-23.

3. O'Sullivan E, Milosevic A, British Society of Paediatric Dentistry. UK National clinical guidelines in paediatric dentistry: diagnosis, prevention and management of dental erosion. Int J Paediatr Dent 2008; 18(Suppl 1): 29-38.

4. Lussi A, Jaeggi T, Zero D. The role of diet in the aetiology of dental erosion. Caries Res 2004; 38(Suppl 1): 34-44.

5. Lussi A, Jaeggi T, Jaeggi-Schärer S. Prediction of the erosive potential of some beverages. Caries Res 1995; 29: 349-354

6. Al-Dlaigan $Y$ H, Shaw L, Smith A. Dental erosion in a group of British 14-year-old school children. Part II: Influence of dietary intake. Br Dent J 2001; 190: 258-261.

7. Grobler S R, Senekal P J, Laubscher J A. In vitro demineralization of enamel by orange juice, apple juice, Pepsi Cola and Diet Pepsi Cola. Clin Prev Dent 1990; 12: 5-9.

8. West N X Maxwell A, Hughes J A, Parker D M Newcombe R G, Addy M. A method to measure clinical erosion: the effect of orange juice consumption on erosion of enamel. J Dent 1998; 26: 329-335.

9. NHS Choices. 5 a day: what counts? NHS, 2009. Online information available at http://www.nhs.uk/ Livewell/5ADAY/Pages/Whatcounts.aspx (accessed December 2012).

10. British Nutrition Foundation. A Healthy Varied Diet. Cited 2013, Feb 12. Online information available at http://www.nutrition.org.uk/healthyliving/ healthyeating/a-healthy-varied-diet?start=3
11. British Soft Drinks Association. Children's consumption of soft drinks. BSDA consumer research 2008. BSDA, 2008. Online report available at http://www. britishsoftdrinks.com/pdf/chidren's\%20consumption $\% 20$ of\%20soft $\% 20 d$ rinks $\% 20$ (high\%20res).pdf (accessed December 2012).

12. Mercer C. Smoothie operators lead UK health binge. Beveragedaily.com 2007. Online article available at http://www.beveragedaily.com/Markets/Smoothieoperators-lead-UK-health-binge (accessed December 2012)

13. The Juice and Smoothie Association. Smoothie history. JASA, 2000. Online article available at http:// www.smoothiecentral.com/Flashsite/index.html (accessed December 2008).

14. Innocent. The basics. What is a smoothie? Online information available at http://www.innocentdrinksforhcps.com/research.php (accessed December 2012).

15. Hughes J A, West N X, Parker D M, van den Braak $\mathrm{M} \mathrm{H}$. Addy $\mathrm{M}$. Effects of $\mathrm{pH}$ and concentration of citric, malic and lactic acids on enamel, in vitro. J Dent 2000; 28: 147-152.

16. Mayes A. The dictionary of nutritional health. $A$ guide to the relation between diet and health. UK: Thorsons Publishers Ltd, 1986.

17. Lussi $A$, Jäggi T, Schärer S. The influence of different factors on in vitro enamel erosion. Caries Res 1993; 27: 387-393.

18. British Soft Drinks Association. A changing climate. The 2008 UK soft drinks report. London: BSDA, 2008. Online report available at http://www.britishsoftdrinks.com/pdf/2008\%20statistics\%20report\%20 low\%20res.pdf (accessed December 2012).

19. Edwards $\mathrm{M}$, Creanor S L Foye $\mathrm{R} H$, Gilmour $\mathrm{WH}$. Buffering capacities of soft drinks: the potential influence on dental erosion. J Oral Rehabil 1999, 26: 923-927.

20. Blacker S M, Creanor S L, Creanor S. An in vitro investigation of the initial $\mathrm{pH}$ and titratable acidity of a selection of fruit smoothies. Dent Update 2011; 38: 604-606, 608-609.

21. Rees J, Loyn T, Gilmour A. Does low acid orange juice equal low erosion? Dent Update 2006; 33: $242-244$

22. Shellis $R$ P, Finke $M$, Eisenberger $M$, Parker D M, Addy M. Relationship between enamel erosion and liquid flow rate. Eur J Oral Sci 2005; 113: 232-238.

23. Syed J, Chadwick R G. A laboratory investigation of consumer addition of UHT milk to lessen the erosive potential of fizzy drinks. Br Dent J 2009; 206: E6.

24. Rees J S. The role of drinks in tooth surface loss. Dent Update 2004; 31: 318-320, 322-324, 326.

25. Grobler S R, Senekal P J, Kotze T J. The degree of enamel erosion by five different kinds of fruit. Clin Prev Dent 1989; 11: 23-28.

26. Bassiouny M A, Yang J, Kuroda S. Topographie and radiographic profile assessment of dental erosion. Part II: effect of citrus fruit juices on human dentition. Gen Dent 2008; 56: 136-143.

27. Barbour M E, Finke M, Parker D M, Hughes J A, Allen G C, Addy M. The relationship between enamel softening and erosion caused by soft drinks at a range of temperatures. J Dent 2006; 34: 207-213.

28. Ehlen L A, Marshall T A, Qian F, Wefel J S, Warren J J. Acidic beverages increase the risk of in vitro tooth erosion. Nut Res 2008; 28: 299-303.

29. Amaechi B T, Higham S M, Edgar W M. Factors influencing the development of dental erosion in vitro: enamel type, temperature and exposure time. J Oral Rehabil 1999; 26: 624-630.

30. Bamise C T, Bamise O F. Quantifying the acidic content of commercial yoghurt drinks in Nigeria. Internet J Dent Sci 2008; 6: DOI: 10.5580/14ff. Online article available at http://www.ispub.com/ journal/the internet_journal of dental science/ volume 6 number 1 7/article/quantifying the acidic_content_of_commercial_yoghurt_drinks in_nigeria.html (accessed December 2012).

31. Touyz L Z . Fruit induced sensitivity of cervical margins. J Dent Assoc S Afr 1983; 38: 199-200.

32. Larsen M J, Nyvad B. Enamel erosion by some soft drinks and orange juices relative to their $\mathrm{pH}$, buffering effect and contents of calcium phosphate. Caries Res 1999; 33: 81-87.

33. Hui Y H, Barta J, Pilar Cano M, Gusek T W, Sidhu J S, Sinha N K. Handbook of fruits and fruit processing. Oxford: Wiley-Blackwell, 2006.

34. Lussi A. Dental erosion: from diagnosis to therapy. Monographs in Oral Science. Basel: Karger Publishers, 2006

35. Barbour M E, Lussi A, Shellis R P. Screening and prediction of erosive potential. Caries Res 2011; 45(Suppl 1): 24-32.

36. Barbour M E, Rees J S. The laboratory assessment of enamel erosion: a review. J Dent 2004; 32: 591-602.

37. West N X, Davies M, Amaechi B T. In vitro and in situ erosion models for evaluating tooth substance loss. Caries Res 2011; 45(Suppl 1): 43-52.

38. Attin T. Methods for assessment of dental erosion. Monogr Oral Sci 2006; 20: 152-172.

39. Lussi A, Kohler N, Zero D, Schaffner M, Megert B. A comparison of the erosive potential of different beverages in primary and permanent teeth using an in vitro model. Eur J Oral Sci 2000; 108: $110-114$.

40. Chu C H, Lo E C. Microhardness of dentine in primary teeth after topical fluoride applications. J Dent 2008; 36: 387-391.

41. Mahoney E K, Kilpatrick N M, Swain M V. Behaviour of primary incisor caries: a micromechanical study. Int J Paediatr Dent 2006; 16: 270-277.

42. Costa C C, Almeida I C, Costa Filho L C. Erosive effect of an antihistamine-containing syrup on primary enamel and its reduction by fluoride dentifrice. Int J Paediatr Dent 2006; 16: 174-180.

43. Basting R T, Rodrigues A L Jr, Serra M C. The effect of $10 \%$ carbamide peroxide, carbopol and/or glycerin on enamel and dentin microhardness. Oper Dent 2005: 30: 608-616.

44. Gedalia I, Dakuar A, Shapira L, Lewinstein I, Goultschin J, Rahamim E. Enamel softening with Coca-Cola and rehardening with milk or saliva. Am J Dent 1991: 4: 120-122.

45. NHS Choices. Sugars. NHS, 2011. Online information available at http://www.nhs.uk/Livewell/Goodfood/ Pages/sugars.aspx (accessed December 2012).

46. British Heart Foundation. Heathy eating on a budget. BHF, 2011. Online article available at http:// www.ohf.org.uk/heart-health/prevention/healthyeating/healthy-eating-on-a-budget.aspx (accessed December 2012)

47. British Nutrition Foundation. Healthy snacking choosing snacks. BNF, 2011. Online article available at http://www.nutrition.org.uk/healthyliving/ healthyeating/healthy-snacking?start=1 (accessed December 2012).

48. Innocent. Are you getting enough? The barriers to getting your 5-a-day and how to help your patients get there. London: Innocent, 2010. Online article available at http://www.innocentdrinksforhcps. com/docs/innocent_5aday_report.pdf (accessed December 2012)

49. Dixey $R$, Heind I L Loureiro I Pérez-Rodrigo $C_{1}$ Snel J, Warnking P. Healthy eating for young people in Europe. A school based nutrition guide. European Network of Health Promoting Schools, 1999. Online article available at http:// ws10.e-vision.nl/she_network/upload/pubs/ HealthyeatingforyoungpeopleinEurope.pdf (accessed December 2012).

50. The Scottish Government. Healthy Eating in Schools: a guide to implementing the nutritional requirements for food and drink in schools (Scotland) regulations 2008. Edinburgh: The Scottish Government, 2008. Online article available at http://www. scotland.gov.uk/Publications/2008/09/12090355/0 (accessed December 2012). 